\title{
PRODUKSI ORGAN BICARA BAHASA ARAB
}

\author{
Raodhatul Jannah \\ Email: raodha_15@yahoo.co.id \\ Madrasah Tsanawiyah DDI Taqwa Parepare
}

\begin{abstract}
ABSTRAK
The field of linguistics that studies, analyzes, and discusses the sequences of language sounds is called phonology. The sound units that are the object of the study are phonetic and phonemic. In the case of issuing, producing, or uttering sounds, of course through the process. Human speech organs consist of the respiratory system, esophagus and oral cavity, nose and throat which then work together to produce a sound, both in the form of consonants and Arabic vowels. The consonant study in this case relates to the characteristics, pronunciation of articulation and the place where the sound is released.
\end{abstract}

Keyword: Arabic, Phonology

\begin{abstract}
ABSTRAK
Bidang linguistik yang mempelajari, menganalisis, dan membicarakan runtutan bunyi-bunyi bahasa disebut Fonologi. Adapun satuan bunyi yang menjadi objek studinya yaitu fonetik dan fonemik. Dalam hal mengeluarkan, menghasilkan, atau mengucapkan bunyi, tentu saja melalui proses. Organ-organ bicara manusia terdiri dari sistem pernafasan, kerongkongan dan rongga mulut, hidung dan tenggorokan yang kemudian bekerja sama menghasilkan sebuah bunyi, baik berupa huruf konsonan maupun vokal bahasa Arab. Kajian konsonan dalam hal ini berkaitan dengan karakteristik, artikulasi pelafalan dan tempat keluarnya bunyi tersebut.
\end{abstract}

Kata Kunci: Bahasa Arab, Fonologi 


\section{PENDAHULUAN}

Ketika mendengar orang berbicara, maka akan terdengar runtutan bunyi bahasa. Runtutan bunyi bahasa ini dapat dianalisis dan disegmentasikan berdasarkan tingkatan-tingkatan kesatuannya yang ditandai dengan hentian-hentian atau jeda yang terdapat dalam runtutan bunyi tersebut. Bidang linguistik yang mempelajari, menganalisis, dan membicarakan runtutan bunyi-bunyi bahasa disebut Fonologi. Adapun satuan bunyi yang menjadi objek studinya yaitu fonetik dan fonemik. Dalam hal mengeluarkan, menghasilkan, atau mengucapkan bunyi, tentu saja melalui proses. Kita perlu mengetahui bagaimana proses pengeluaran bunyibunyi bahasa dan organ-organ apa saja yang berperan dalam proses tersebut.

Proses terbentuknya bunyi bahasa tidak dapat terlepas dari peran organ-organ tubuh bicara manusia. Organ-organ ini kemudian bekerja sama menghasilkan sebuah bunyi, baik berupa huruf konsonan maupun vokal bahasa Arab. Kajian konsonan dalam hal ini berkaitan dengan karakteristik, artikulasi pelafalan dan tempat keluarnya bunyi tersebut. Dengan demikian, pemahaman mengenai hal ini dirasa sangat penting sebagai dasar dalam mempelajari fonologi.

Berangkat dari persepsi tersebut, makalah ini akan membahas bagaimana proses keluarnya bunyi bahasa Arab yang berkaitan dengan organ bicara, karakteristik bunyi dan artikulasinya serta tempat keluarnya bunyi tersebut.

\section{PEMBAHASAN}

\section{A. Organ-Organ Bicara}

Proses bicara melibatkan beberapa sistem dan fungsi tubuh, baik sistem pernafasan, kerongkongan dan rongga mulut, hidung dan tenggorokan. ${ }^{1}$

\section{Alat-Alat Pernapasan} berikut.

Organ-organ yang terpenting dalam pernapasan adalah sebagai

\footnotetext{
${ }^{1}$ Yusuf Rohani, "Organ Bicara dan Fungsinya" blog pribadi Yusuf Rohani http://yusufrokhani.blogspot.co.id/2013/12/organ-bicara-dan-fungsinya.html diakses tanggal 14 April 2018
} 


\section{a. Rongga Dada/Chest Ribs}

Rongga dada terdiri atas tulang dada di bagian depan, 12 pasang rusuk di bagian kiri dan kanan, dan 12 cabang rusuk di tulang punggung belakang. Sepuluh pasang di antaranya bersambung dari belakang ke depan, sedangkan dua pasang tidak bersambung. Hal itulah yang membuat rongga dada dapat mengembang dan mengempis.

Dalam proses bicara, organ-organ ini berfungsi menekan rongga dada ke arah paru-paru dengan tekanan yang sangat rapi dan tingkat yang beda-beda. Setiap tekanan yang dilakukan mengakibatkan arus keluar udara, sesuai dengan jumlah dan tingkat tekanan yang dilakukan. Proses inilah yang mengakibatkan terjadinya penggalan dalam suatu kata.

b. Sekat Rongga Dada/Diaphragm

Organ ini terdiri atas susunan otot yang bentuknya melebar dan dapat bergerak. Organ inilah yang memisahkan antara alat-alat pernapasan dengan alat-alat pencernaan. Fungsi dari organ yang bergerak turun naik ini adalah sebagai penekan paru-paru lewat tekanan terhadap rongga dada.Tinggi rendahnya tekanan yang terjadi tergantung dengan bagian kata yang akan dituturkan atau kejiwaan seseorang saat menuturkannya. Tekanan inilah yang mengakibatkan adanya unsur letupan dalam bunyi bahasa.

\section{c. Paru-paru/lungs}

Paru-paru adalah organ yang bersifat elastis yang dapat berkembang dan mengempis. Organ ini terdiri dari penampung udara, saluran udara, dan pembuluh darah. Paru-paru yang terdiri dari bagian kiri dan kanan dihubungkan dengan saluran udara oleh dua cabang penyalur udara. Pengembangan dan pengempisan paru-paru terjadi akibat tekanan yang dilakukan oleh rongga dada dan sekat rongga dada secara serempak.

Dalam berbicara udara yang berasal dan keluar dari paru-paru mutlak sangat diperlukan, mengingat bahwa bunyi bahasa Indonesia dan bahasa Arab tidak ada yang menggunakan udara yang berasal dari luar, tetapi semua menggunakan udara yang keluar dari paru-paru. Tempo yang digunakan dalam penarikan dan penghembusan napas adalah sama ketika tidur atau istirahat, sedangkan saat lelah dan sakit tempo untuk menarik napas tampak lebih panjang.

d. Saluran Udara/Trachea 
Saluran udara ini biasa juga disebut dengan khalqum, yaitu sebuah pipa udara yang terbuat dari cincin-cincin tulang rawan yang terletak di atas paru-paru dan di bawh kerongkongan sepanjang $12 \mathrm{~cm}$ dengan jari-jari 2 s.d. $21 / 2 \mathrm{~cm}$. Saluran ini mempunyai dua cabang yang menghubungkannya dengan kedua belah paru, kiri dan kanan.

Di bagian belakang dari saluran udara ini terdapat saluran makanan dan minuman dari mulut ke bagian pencernaan.

Fungsi saluran udara dalam bicara adalah sebagai tempat lalunya udara yang merupakan bahan baku dari suatu bunyi yang datang dari paru-paru untuk diteruskan ke rongga mulut dan rongga hidung, di samping itu, saluran udara ini juga berfungsi sebagai koyak resonansi beberapa jenis bunyi.

\section{Kerongkongan/larynx}

Kerongkongan yang berbentuk kotak kecil ini teletak di antara ujung sebelah atas saluran udara dan pangkal dari rongga tenggorokan. Bagian depan dari kerongkongan ini biasa disebut dengan istilah jakun.

Kerongkongan terdiri atas tiga tulang rawan, yang pertama disebut dengan "tiroid" yang terletak di bagian atas, berbentuk setengah lingkaran di sebelah belakang dan melebar di bagian depan, bagian ke dua adalah tulang rawan bundar yang disebut dengan "krikoid" yang terletak di bawah tiroid, sedangkan yang ke tiga adalah "aritenoid" yang terdiri dari dua buah tulang rawan yang terletak di atas tulang rawan krikoid. Dua buah tulang rawan kecil ini dihubungkan dengan engsel dan urat pengikat.

Organ bicara yang paling penting dari kerongkongan ini adalah dua buah pita suara/vokal cords, yaitu dua buah pita lebar memanjang dari belakang sampai belakang jakun. Diantara dua pita ini terdapat klep yang disebut glotis. Dari klep inilah udara akan keluar menuju mulut.

Pita suara dapat membentuk berbagai macam bentuk ketika menghadapi udara yang datang dari paru-paru, yang mengakibatkan terjadinya variasi bunyi yang dihasilkan. Di antara posisi pita suara tersebut adalah posisi rapat/menutup, posisi berjauhan/terbuka, posisi bergesekan/bersentuhan dan posisi berdekatan.

\section{Organ Bicara di Atas Kerongkongan}

Organ bicara ini terdiri atas beberapa bagian berikut ini: 


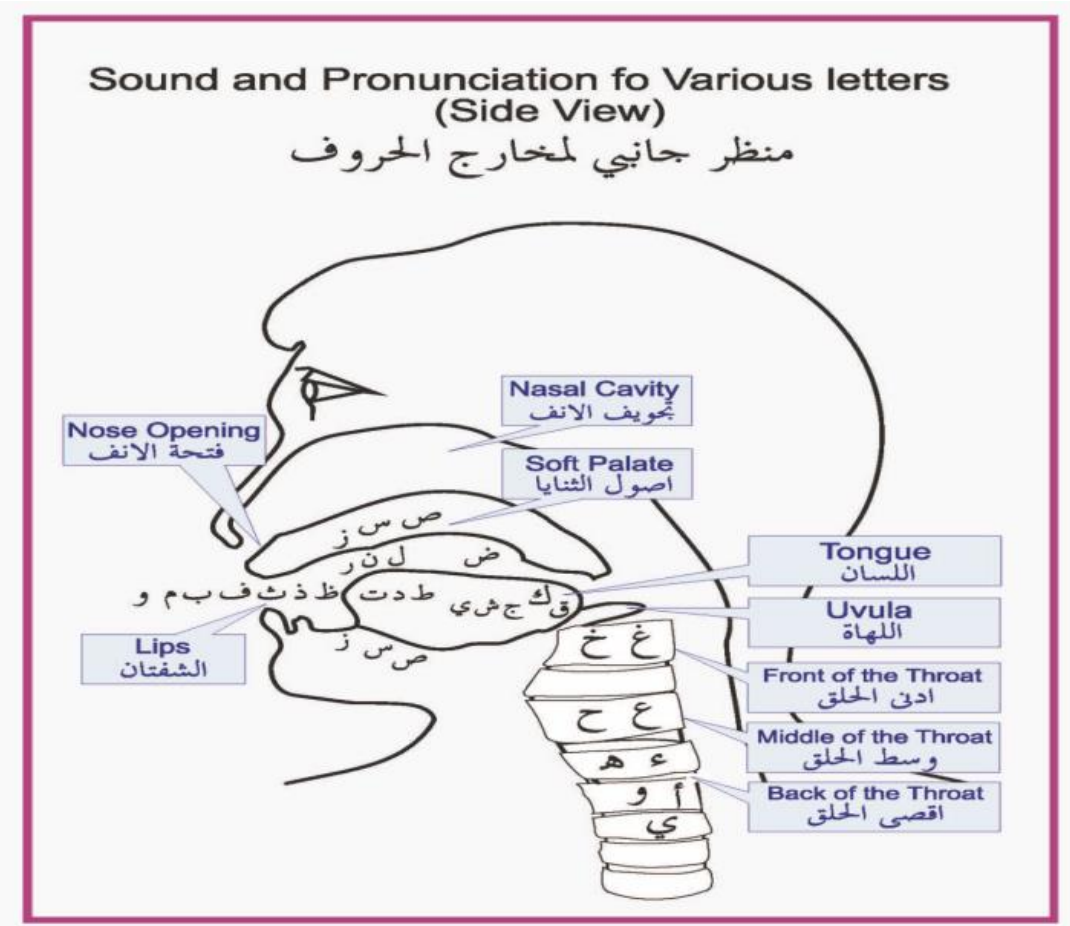

\section{a. Tenggorokan}

Tenggorokan adalah sebuah rongga yang terletak di antara kerongkongan dengan mulut yang bentuknya mirip dengan pipa. Apabila pangkal lidah mundur dan menekan dinding tenggorokan maka rongga tengorokan tersebut menjadi menyempit, sehingga memperngaruhi arus udara yang datang dari paru-paru. Tenggorokan ini juga merupakan makhraj dari beberapa bunyi Arab, seperti ('AinHa), dalam ilmu tajwid huruf-huruf tersebut disebut huruf halaqiah (bunyi-bunyi tenggorokan).

b. Lidah/Tounge (اللسان)

Lidah adalah sejenis otot yang memenjang di rongga mulut.Organ ini terdiri dari beberapa unsur yang tersusun secara rapi, seperti otot-otot dan syaraf-syaraf. Di bagian ujung lidah terdapat semacam syaraf yang berfungsi sebagai alat perasa. Lidah termasuk organ bicara yang paling aktif, dengan gerakan-gerakan tertentu dari bagian-bagian lidah seperti dijelaskan di atas bertemu 
dengan organ bicara pasif sehingga terjadilah bunyi yang mempunyai ciri tersendiri.

c. Langit-langit/Palate (الصلب الحنق)

Langit-langit terletak dibagian atas rongga mulut yang memanjang dari pangkal gigi di bagian depan sampai anak lidah (tegak) di bagian belakang. Para ahli membagi langit-langit kedalam tiga bagian, yaitu

1. Bagian depan yang disebut dengan gusi/alveloar,

2. Langit-langit keras/palate, dan

3. Langit-langit lunak/velar

Langit-langit termasuk organ yang pasif, kecuali langit-langit lunak yang bisa bergerak mundur ke belakang dan bekerja sama dengan tekak untuk membuka dan menutup saluran udara ke hidung.

Kerja sama antara langit-langit lunak dengan bagian lidah sangat besar fungsinya dalam membuat rongga mulut sebagai kontak resonansi untuk beberapa bunyi tertentu. Disamping itu, langit-langit lunak dapat mengubah alur udara yang keluar melalui rongga mulut menjadi keluar dari rongga hidung dengan membuka klep udara menuju hidung, atau sebaliknya.

d. Anak Lidah/Tekak/Uvula ( اللهاة )

Anak lidah terdapat dibagian atas, antara langit-langit lunak dengan tenggorokan, diantara rongga mulut dengan rongga hidung. Fungsinya hampir sama dengan fungsi langit-langit lunak.Langitlangit lunak dapat bergerak menutup klep udara yang menuju ke rongga hidung, sehingga bunyi akan keluar dari rongga hidung. Disamping itu kerja sama dengan anak lidah dengan pangkal lidah merupakan makhraj bunyi (qof).

e. Gigi/Dental (الأسنان)

Gigi terdapat di belahan mulut atas dan belahan mulut bawah.Walaupun gigi bawah dapat bergerak, namun tidak banyak berfungsi dalam pembentukan bunyi bahasa jika dibandingkan dengan organ bicara aktif lainnya, seperti lidah dan bibir bawah.

Fungsi gigi sebagai organ bicara sangat jelas karena merupakan penghambat udara yang datang dari paru-paru,sehingga tidak keluar secara serentak dari rongga mulut.

f. Bibir/Labial (الشفتان)

Bibir merupakan dua pita yang terdapat di pintu rongga mulut.bibir terdiri atas otot-otot yang membuatnya dapat bergerak 
dengan lincah, cepat dan teratur sesuai dengan jenis bunyi yang akan dituturkan.

g. Rongga hidung/Nasal cavity ( تجويف الأنف)

Rongga hidung adalah saluran udara yang terdapat di belakang lubang hidung dan memanjang sampai ke langit-langit lunak.didalam rongga hidung terdapat areal-areal kosong, di antaranya yang disebut dengan kantong hidung.

Fungsi rongga hidung dalam bicara jelas tampak ketika klep rongga hidung terbuka sehingga udara keluar dari rongga hidung,atau klep tersebut tertutup.sehingga udara keluar dari rongga mulut.Kondisi pertama akan menghasilkan bunyi seperti ( nun mim )' $n g$, ny'sedangkan kondisi kedua akan menghasilkan bunyi mulut seperti ( $t a-t s a-b a$ )dan lain-lain. ${ }^{2}$

\section{B. Konsonan dalam Bahasa Arab}

Konsonan adalah "bunyi bahasa yang dihasilkan dengan menghambat aliran udara pada salah satu tempat di saluran suara di atas glotis". 3 Dari sumber yang lain, konsonan adalah bunyi letupan, bunyi geseran, bunyi bersuara. Konsonan selalu mendapatkan hambatan kuat atau lemah sehingga mengakibatkan adanya letupan atau geseran. ${ }^{4}$

Untuk mengetahui semua konsonan bahasa Arab yang diajarkannya, mengetahui artikulator, cara mengucapkannya dan karakter bersuara atau tak bersuara dari masing-masing konsonan terdapat beberapa hal yang harus diperhatikan. Adapun konsonan arab dan karakteristiknya bisa dilihat pada uraian berikut :

Tabel 2.1 Konsonan Bahasa Arab dan Karakteristiknya ${ }^{5}$

\begin{tabular}{|l|l|l|}
\hline $1-$ & Hambat Bilabial Bersuara & $\varphi$ \\
\hline
\end{tabular}

2 Yusuf Rohani, "Organ Bicara dan Fungsinya" blog pribadi Yusuf Rohani http://yusufrokhani.blogspot.co.id/2013/12/organ-bicara-dan-fungsinya.html diakses tanggal 14 April 2018.

3 Sakholid,Pengantar Linguistik, analisis teori-teori linguistic dalam bahasa arab,(Medan,Nara Press,2006) hal. 73.

${ }^{4}$ Fanin, "Pembagian Konsonan dalam Bahasa Arab" blog pribadi Fanin https://www.fanind.com/pembagian-konsonan-dalam-bahasa-arab.html diakses tanggal 13 April 2018.

${ }^{5}$ Abdul Rahim, "Unsur-Unsur Bahasa" blog pribadi Abdul Rahim http://arohim600.blogspot.co.id/2015/03/makalah-aswat.html diakses tanggal 13 April 2018. 


\begin{tabular}{|c|c|c|}
\hline & وقفي الثفتان المجهور & \\
\hline \multirow{2}{*}{ Y- } & Hambat dental tak bersuara & \multirow[t]{2}{*}{$ت$} \\
\hline & إق وقفي الأثنان المهموس & \\
\hline \multirow[t]{2}{*}{ r- } & Hambat dental bersuara & \multirow[t]{2}{*}{ د } \\
\hline & المقي الأثنان المجهور & \\
\hline \multirow[t]{2}{*}{$\varepsilon_{-}$} & Hambat dental ditekan tak bersuara & \multirow[t]{2}{*}{$b$} \\
\hline & إل وقفي الأثنان المهموس & \\
\hline \multirow[t]{2}{*}{$0_{-}$} & Hambat dental ditekan bersuara & \multirow[t]{2}{*}{ 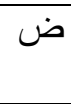 } \\
\hline & و وقفي الأثنان المجهر & \\
\hline \multirow[t]{2}{*}{$7-$} & Hambat velar tak bersuara & \multirow[t]{2}{*}{ ك } \\
\hline & وقفي الطبقي المهموس & \\
\hline \multirow[t]{2}{*}{$V_{-}$} & Hambat velar bersuara & \multirow[t]{2}{*}{ ق } \\
\hline & وقفي الطبقي المجهور & \\
\hline \multirow[t]{2}{*}{$\Lambda_{-}$} & Hambat glotal tak bersuara & \multirow[t]{2}{*}{$\&$} \\
\hline & وقفي حنجري المهموس & \\
\hline \multirow[t]{2}{*}{9} & Arikatif alveolar bersuara & \multirow[t]{2}{*}{ ج } \\
\hline & إل مركبا للثوي الغاري المجهور & \\
\hline \multirow[t]{2}{*}{$1 \cdot-$} & Frikatif labiodental tak bersuara & \multirow[t]{2}{*}{ ف } \\
\hline & احتكاكي الثفوي الأثنان المهموس & \\
\hline \multirow[t]{2}{*}{$11-$} & Frikatif interdental tak bersuara & \multirow[t]{2}{*}{$\dot{H}$} \\
\hline & ا احتكاكي بين اثنان المهموس & \\
\hline \multirow[t]{2}{*}{ IY } & Frikatif interdental bersuara & \multirow[t]{2}{*}{$\dot{j}$} \\
\hline & احتكاكي بين الاثنان المجهور & \\
\hline \multirow[t]{2}{*}{$1 \mu_{-}$} & Frikatif apikoalveolar bersuara & \multirow[t]{2}{*}{ j } \\
\hline & احتكاكي اللثتوي المجهور & \\
\hline \multirow[t]{2}{*}{$1 \varepsilon_{-}$} & Frikatif apikoalveolar ditekan tak bersuara & \multirow[t]{2}{*}{ ص } \\
\hline & احتكاكي اللثوي المهموز & \\
\hline \multirow[t]{2}{*}{$10_{-}$} & Frikatif interdental ditekan bersuara & \multirow[t]{2}{*}{ ظ } \\
\hline & احتكاكي بين الاثنان المجهور & \\
\hline \multirow[t]{2}{*}{17.} & Frikatif palatal tak bersuara & \multirow[t]{2}{*}{ ش } \\
\hline & احتكاكي اللثوي الغاري المهوس & \\
\hline \multirow[t]{2}{*}{ IV- } & Frikatif velar tak bersuara & $\dot{\tau}$ \\
\hline & احتكاكي الطبقي المجهور & \\
\hline
\end{tabular}




\begin{tabular}{|c|c|c|}
\hline \multirow[t]{2}{*}{$1 \Lambda_{-}$} & Frikatif velar tak bersuara & \multirow[t]{2}{*}{$\tau$} \\
\hline & احتكاكي الحلقي المهمو & \\
\hline \multirow[t]{2}{*}{19} & frikatif uvular bersuara & \multirow[t]{2}{*}{$\varepsilon$} \\
\hline & احتكاكي الحلقي المجهور & \\
\hline \multirow[t]{2}{*}{$r \cdot-$} & Frikatif glottal tak bersuara & \multirow[t]{2}{*}{$\circ$} \\
\hline & احتكاكي الحنجري المهموس & \\
\hline \multirow[t]{2}{*}{ Y) } & Nasal bilabial bersuara & \multirow[t]{2}{*}{ s } \\
\hline & أنفي الثفتان المجهور & \\
\hline \multirow[t]{2}{*}{ YY } & Nasal apikoalveolar bersuara & \multirow[t]{2}{*}{ ن } \\
\hline & أنفي اللثوي المجهور & \\
\hline \multirow[t]{2}{*}{$r_{-}$} & Nasal latelar bersuara & \multirow[t]{2}{*}{ ل } \\
\hline & أنفي الجانب المجهور & \\
\hline \multirow[t]{2}{*}{$r \varepsilon_{-}$} & Getar apikoalveolar bersuara & \multirow[t]{2}{*}{ 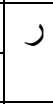 } \\
\hline & الكرر اللثوي المجهور & \\
\hline \multirow[t]{2}{*}{ ro- } & Semivokal bilabial bersuara & \multirow[t]{2}{*}{ g } \\
\hline & شبه الصائت الثفوي المجهور & \\
\hline \multirow[t]{2}{*}{$r \tau_{-}$} & Semivokal palatal bersuara & \multirow[t]{2}{*}{ ي } \\
\hline & شبه الصائت الغار المجهور & \\
\hline
\end{tabular}

a. Jika kita perhatikan, cara artikulasi pelafalan konsonan Arab dapat dikelompokan sebagai berikut :

Tabel 2.2 Artikulasi Pelafalan Konsonan Bahasa Arab

\begin{tabular}{|c|c|c|c|}
\hline No & $\begin{array}{c}\text { Jenis Hambatan } \\
\text { نوع العقبة }\end{array}$ & $\begin{array}{c}\text { Keterangan } \\
\text { معلومات }\end{array}$ & $\begin{array}{l}\text { Simbol Bunyi } \\
\text { رموص الاصوات }\end{array}$ \\
\hline 1 & $\begin{array}{l}\text { stop/hambar } \\
\text { (وقفي) }\end{array}$ & $\begin{array}{l}\text { Bunyi yang berhenti selepas } \\
\text { pengucapannya dengan cara } \\
\text { menahan nafas dengan dua } \\
\text { bibir atau lidah lalu } \\
\text { dilepaskan sekaligus. }\end{array}$ & 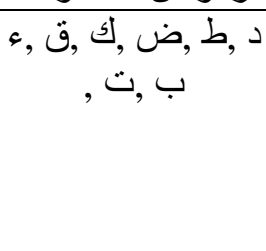 \\
\hline 2 & $\begin{array}{l}\text { Affrikat/paduan } \\
\text { (majziyah) }\end{array}$ & $\begin{array}{l}\text { Bunyi hambat yang diikuti } \\
\text { bunyi desis }\end{array}$ & ج \\
\hline 3 & $\begin{array}{l}\text { Frikatif/geseran } \\
\text { (احتكاكي) }\end{array}$ & $\begin{array}{l}\text { Pada bunyi bahasa ini, arus } \\
\text { udara melalui saluran } \\
\text { sempit lalu akan terdengar } \\
\text { bunyi desis }\end{array}$ & 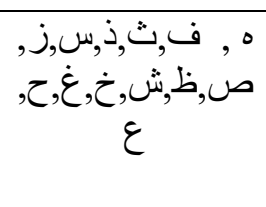 \\
\hline 4 & Nasal/sengawuan & Bunyi yang keluar lewat & مرن \\
\hline
\end{tabular}




\begin{tabular}{|c|c|c|c|}
\hline & (أنفي) & hembusan udara dari hidung & \\
\hline 5 & $\begin{array}{l}\text { Lateral/sampingan } \\
\text { (جانبي) }\end{array}$ & $\begin{array}{l}\text { Bunyi yang keluar melalui } \\
\text { hembusan udara dari } \\
\text { samping mulut }\end{array}$ & J \\
\hline 6 & $\begin{array}{l}\text { Getar } \\
\text { (مكرر ) }\end{array}$ & $\begin{array}{l}\text { Bunyi yang keluar melalui } \\
\text { getaran lidah sebagai akibat } \\
\text { bersentuhannya ujung lidah } \\
\text { dengan gigi }\end{array}$ & J \\
\hline 7 & $\begin{array}{l}\text { Semivokal (Syibh } \\
\text { sha'aitah) }\end{array}$ & $\begin{array}{l}\text { Bunyi yang diucapkan } \\
\text { seperti huruf vokal, tetapi } \\
\text { bunyinya pecah seperti } \\
\text { huruf konsonan. }\end{array}$ & ي ,و \\
\hline
\end{tabular}

b. Sedangkan dilihat dari artikulatornya letak atau tempat pengucapan dapat dikategorikan sebagai berikut :

Tabel 2.3 Artikulator dan Tempat Pengucapan Konsonan Bahasa Arab

\begin{tabular}{|c|c|c|c|}
\hline No & $\begin{array}{c}\text { Tempat Hambatan } \\
\text { مكان العقبة }\end{array}$ & $\begin{array}{l}\text { Keterangan } \\
\text { معلومات }\end{array}$ & $\begin{array}{l}\text { Simbol Bunyi } \\
\text { رموص الاصوات }\end{array}$ \\
\hline 1 & $\begin{array}{l}\text { Bilabial } \\
\text { (شفوي) }\end{array}$ & $\begin{array}{l}\text { Bunyi yang keluar lewat } \\
\text { bibir atas dan bibir bawah } \\
\text { secara bersamaan }\end{array}$ & ب ,م, رو \\
\hline 2 & $\begin{array}{l}\text { Labiodental } \\
\text { (أثناني شفوي) }\end{array}$ & $\begin{array}{l}\text { Bunyi yang keluar lewat } \\
\text { bibir bawah dan gigi atas }\end{array}$ & ف \\
\hline 3 & $\begin{array}{l}\text { Dental } \\
\text { (أثناني) }\end{array}$ & $\begin{array}{l}\text { Bunyi yang keluar melalui } \\
\text { ujung lidah dan gigi bagian } \\
\text { dalam }\end{array}$ & ت ,د ,ط ,ض \\
\hline 4 & $\begin{array}{l}\text { Interdental } \\
\text { (bai'asnaniyyah) }\end{array}$ & $\begin{array}{l}\text { Bunyi yang keluar dari } \\
\text { ujung lidah antara gigi atas } \\
\text { dan gigi bawah }\end{array}$ & تُ,ذ,ص ,ظ \\
\hline 5 & $\begin{array}{l}\text { Alfeolar } \\
\text { (لثوي) }\end{array}$ & $\begin{array}{l}\text { Bunyi yang dihasilkan oleh } \\
\text { berdekatannya } \\
\text { bersentuhannya ujung lidah }\end{array}$ & س ,ز ,ل ,ن ,ر \\
\hline
\end{tabular}




\begin{tabular}{|c|c|c|c|}
\hline & & dengan gusi atas & \\
\hline 6 & $\begin{array}{l}\text { Alveolar palatal } \\
\text { (لثوي الغاري) }\end{array}$ & $\begin{array}{l}\text { Bunyi yang keluar lewat } \\
\text { lidah mendekati gusi }\end{array}$ & ج \\
\hline 7 & $\begin{array}{l}\text { Palatal } \\
\text { (غاري) }\end{array}$ & $\begin{array}{l}\text { Bunyi yang dihasilkan oleh } \\
\text { berdekatannya atau } \\
\text { bersentuhannya ujung lidah } \\
\text { dengan langit-langit mulut. }\end{array}$ & ي \\
\hline 8 & $\begin{array}{l}\text { Velar } \\
\text { (طبقي) }\end{array}$ & $\begin{array}{l}\text { Bunyi yang keluar lewat } \\
\text { pangkal lidah dan belakang } \\
\text { pangkang langit-langit. }\end{array}$ & 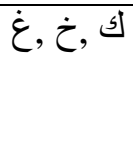 \\
\hline 9 & $\begin{array}{l}\text { Uvular } \\
\text { (حلقي) }\end{array}$ & $\begin{array}{l}\text { Bunyi yang keluar } \\
\text { melalui halq } \text { kerongkongan }\end{array}$ & ق ,ح, ,ع \\
\hline 10 & $\begin{array}{l}\text { Glottal } \\
\text { (حنجري) }\end{array}$ & $\begin{array}{l}\text { Bunyi yang keluar melalui } \\
\text { tenggorokan. }\end{array}$ & $0, c$ \\
\hline
\end{tabular}

c. Dilihat dari segi bersuara atau tidaknya, konsonan Arab dapat dikelompokan sebagai berikut :

Tabel 2.4 Bersuara atau Tidaknya Konsonan Bahasa Arab

\begin{tabular}{|c|c|c|c|}
\hline 1. & $\begin{array}{l}\text { Konsonan tak } \\
\text { bersuara } \\
\text { (مهوسوس) }\end{array}$ & $\begin{array}{l}\text { Bunyi yang keluar tanpa } \\
\text { menggetarkan pita suara. }\end{array}$ & 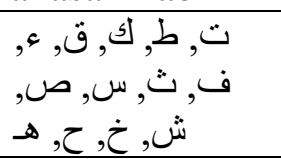 \\
\hline 2. & $\begin{array}{l}\text { Konsonan Bersuara } \\
\text { (مجهور) }\end{array}$ & $\begin{array}{l}\text { Bunyi yang keluar dengan } \\
\text { menggetarkan pita suara. }\end{array}$ & 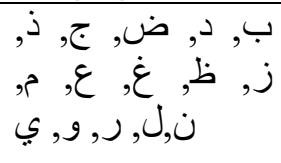 \\
\hline
\end{tabular}

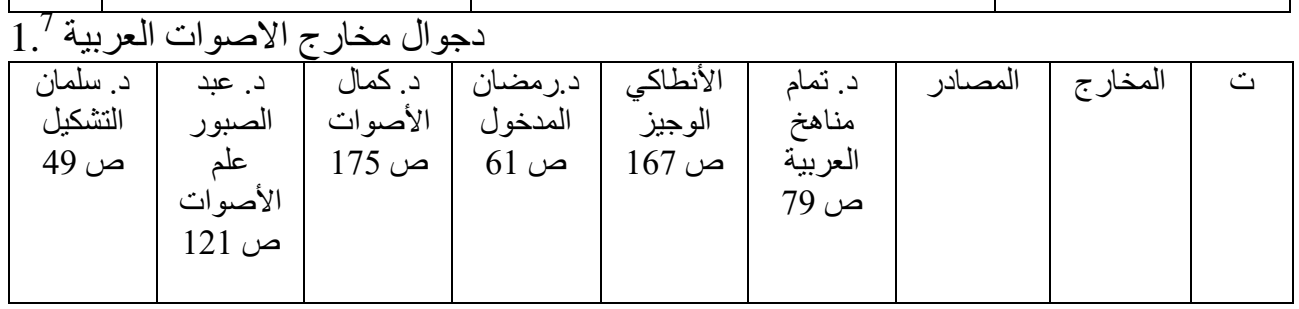

${ }^{6}$ Abdul Rahim, "Unsur-Unsur Bahasa" blog pribadi Abdul Rahim http://arohim600.blogspot.co.id/2015/03/makalah-aswat.html diakses tanggal 13 April 2018.

${ }^{7}$ Hanam Kaduri Hamid, "al-Madhul ilaa 'Ilm al-Aswat al-Arabiyyah"(al-Majma' al-'`lm, 2004), h. 182. 


\begin{tabular}{|c|c|c|c|c|c|c|c|}
\hline ب مو & ب م و & ب م و & ب م و & ب مو & ب مو & شفوي & -1 \\
\hline ف & ف & ف & ف & ف & ف & شفوي اسناني & $-r$ \\
\hline ظ ذ ث & ظذذ ث & ظذ ث & ظذ ث & ظذ ث & ظذذ ث & اسناني & $-r$ \\
\hline ص ط ط س ل & ض ت د ط ن & ض د د ن & س س ط ض ض & ض ص د س س س & ض ض د س ص & اسناني لثوي & $-\varepsilon$ \\
\hline- & ز صر & ز ص صر & ل ر ن & ل ر ن & ل ر ن & لثوي & -0 \\
\hline- & ش ج & ش ج & - & - & - & غاري ملتى & -7 \\
\hline ج ش ي & ي & ي & ج يش & ش ج ي & ش ج ي & غاريّ & $-V$ \\
\hline ك خ & ك (و) & $\begin{array}{l}\dot{\tau} \dot{\varepsilon} \text { (و) } \\
\text { (و) }\end{array}$ & ك ك غ & ك & ك & طبقيّ & $-\Lambda$ \\
\hline ق غ غ & ق غ & ق & ق & ق & ق غ & لهوي & -9 \\
\hline$\tau \varepsilon$ & $\tau \varepsilon$ & $\tau \varepsilon$ & $\tau \varepsilon$ & $\tau \varepsilon$ & $\tau \varepsilon$ & حلقي & -1. \\
\hline $0 \&$ & $0=$ & $0<$ & $0 \&$ & $0 \&$ & $0 \&$ & حنجري & -11 \\
\hline
\end{tabular}

C. Bunyi dengan Arus Udara Egresif dan Bunyi dengan Arus Ingresif

Arah arus udara dalam pembentukan bunyi bahasa dapat dibedakan atas egresif dan in-gresif. Dalam kebanyakan bunyi bahasa, pembentukan bunyi itu dilaksanakan dengan arus udara keluar dari paru-paru, arus udara demikian disebut egresif. Namun, dalam bahasa-bahasa tertentu dapat juga bunyi itu terbentuk dengan arah udara masuk kedalam paru-paru, jika demikian arah udara itu disebut in-gresif. Arus udara egresif dapat dibagi lagi menjadi dua yaitu egrsif pulmonik dan egresif glotalik. Begitu juga arus udara in-gresif dapatdibagi menjadi dua yaitu, in-gresif glotalik dan ingresif velarik.

a. Egresif pulmonik adalah bunyi yang terbentuk dengan arus udara egresif (keluar) dengan mekanisme pulmonik. Mekanisme udara pulmonik ialah udara dari paru-paru sebagai sumber utamanya dihembuskan keluar dengan cara mengecilkan ruangan paru-paru, otot perut dan rongga dada.

b. Egresif glotalik adalah bunyi yang terbentuk dengan arus udara egresif (keluar) dengan mekanisme glotalik. Mekanisme glotalik 
terjadi dengan cara merapatkan pita-pita suara sehingga glotis dalam keadaan tertutup rapat sekali.

c. Ingresif glotalik adalah bunyi bahasa yang terbentuk dengan arus udara ingresif (masuk) dengan mekanisme glotalik. Bunyi dengan arus udara ingresif mekanisme glotalik ini mungkin secara sempurna prosesnya sama dengan egresif glotalik diatas. Jadi, merapatkan pitapita suara sehingga glotis tertutup rapat sekali. Hanya bersama-sama dengan itu rongga pangkal tenggorok yang disempitkan itu diturunkan tidak dinaikan, kemudian udara masuk.

d. Ingresif velarik adalah bunyi bahasa yang terbentuk dengan arus udara ingresif (masuk) dengan mekanisme velarik.mekanisme udara velarik terjadi dengan menaikkan pangkal lidah ditempelkan pada langit-langit lunak. Bersama-sama dengan itu kedua bibir ditutup rapat kemudian ujung lidah dan kedua sisi lidah merapat pada gigi atau gusi dalam itu dilepaskan turun serta di kebelakangkan, bibir dibuka sehingga ada kerenggangan ruangan udara pada rongga mulut. Dengan demikian memungkinkan udara luar untuk masuk. ${ }^{8}$

\section{KESIMPULAN}

Organ-organ bicara manusia terdiri dari sistem pernafasan, kerongkongan, rongga mulut, hidung dan tenggorokan yang saling bekerja sama untuk menghasilkan bunyi bahasa Arab. Untuk mengetahui bunyi konsonan bahasa Arab perlu mengetahui artikulator, cara mengucapkannya dan karakter bersuara atau tak bersuara dari masing-masing konsonan. Selain itu juga harus memperhatikan arah arus udara dalam pembentukan bunyi bahasa.

\section{DAFTAR PUSTAKA}

Rohani, Yusuf. "Organ Bicara dan Fungsinya" blog pribadi Yusuf Rohani http://yusufrokhani.blogspot.co.id/2013/12/organ-bicara-danfungsinya.html diakses tanggal 14 April 2018.

\footnotetext{
${ }^{8}$ Putra Swarnadwipa, "Klasifikasi Bunyi Bahasa” blog pribadi Putra Swarnadwipa http://1sajak.blogspot.co.id/2013/12/klasifikasi-bunyi-bahasa-vokal-konsonan.html diakses tanggal 14 April 2018.
} 
Sakholid. 2006. Pengantar Linguistik, analisis teori-teori linguistic dalam bahasa arab. Medan: Nara Press.

Fanin. "Pembagian Konsonan dalam Bahasa Arab" blog pribadi Fanin https://www.fanind.com/pembagian-konsonan-dalam-bahasaarab.html diakses tanggal 13 April 2018.

Rahim, Abdul. "Unsur-Unsur Bahasa" blog pribadi Abdul Rahim http://arohim600.blogspot.co.id/2015/03/makalah-aswat.html diakses tanggal 13 April 2018.

Hamid, Hanam Kaduri. 2004. "al-Madhul ilaa 'Ilm al-Aswat al-Arabiyyah". al-Majma' al-'Ilm.

Swarnadwipa, Putra. "Klasifikasi Bunyi Bahasa" blog pribadi Putra Swarnadwipa http://1sajak.blogspot.co.id/2013/12/klasifikasibunyi-bahasa-vokal-konsonan.html diakses tanggal 14 April 2018. 